\title{
PENGARUH KEPEMILIKAN INSTITUSIONAL DAN KEPEMILIKAN MANAJERIAL TERHADAP NILAI PERUSAHAAN
}

\author{
Putu Cita Ayu') \\ Ni Komang Sumadi ${ }^{2)}$ \\ 1),2) Universitas Hindu Indonesia, e mail: citaayu87@gmail.com
}

\begin{abstract}
The main purpose of the company is to increase the value of the company. With the achievement of high corporate value, the prosperity for shareholders can increase. Factors that can affect the value of the company is the ownership structure of the company.

This study aims to determine the effect of institutional ownership and managerial ownership of corporate value. The value of the company in this study is proportional to the value of Tobin's Q. The population of this study is a manufacturing company listed on the Indonesia Stock Exchange (IDX) during the period 2014-2016. The method of analysis in this study using multiple linear regression.

The results of this study indicate that institutional ownership positively affects the value of the company while managerial ownership does not affect the value of the company.
\end{abstract}

\section{Keywords: Firm Value, Institutional Ownership, Managerial Ownership}

\section{PENDAHULUAN}

Mendirikan sebuah perusahaan tentunya didasari dengan suatu tujuan. Tujuan dari pendirian sebuah perusahaan adalah untuk memperoleh keuntungan atau laba yang sebesar-besarnya serta untuk memakmurkan pemilik perusahaan atau para pemilik saham (stockholders). Nilai perusahaan adalah merupakan persepsi investor terhadap suatu perusahaan yang berkaitan dengan harga saham. Suatu perusahaan dikatakan mempunyai nilai yang baik jika kinerja perusahaan tersebut juga baik. Semakin tinggi harga saham, maka semakin tinggi pula nilai perusahaan. Investor cenderung lebih tertarik menanamkan sahamnya pada perusahaan yang memiliki kinerja baik dalam meningkatkan nilai perusahaan.

Naik turunnya harga saham di pasar modal menjadi sebuah fenomena yang menarik untuk dibicarakan berkaitan dengan isu naik turunnya nilai perusahaan itu sendiri. Krisis 
ekonomi global yang terjadi pada tahun 2008 berdampak terhadap pasar modal Indonesia yang tercermin dari terkoreksi turunnya harga saham hingga 40-60 persen dari posisi awal tahun 2008, yang disebabkan oleh aksi melepas saham oleh investor asing yang membutuhkan likuiditas dan diperparah dengan aksi "ikut-ikutan" dari investor domestik yang ramai-ramai melepas sahamnya. Kondisi tersebut secara harafiah akan mempengaruhi nilai perusahaan.

Perusahaan manufaktur dipilih sebagai objek penelitian dikarenakan perusahaan manufaktur merupakan perusahaan yang menjual produknya yang dimulai dengan proses produksi yang tidak terputus mulai dari pembelian bahan baku, proses pengolahan bahan hingga menjadi barang jadi. Perusahaan manufaktur lebih membutuhkan sumber dana jangka panjang untuk membiayai operasi perusahaan mereka, salah satunya dengan investasi saham oleh para investor, sehingga dapat mempengaruhi nilai perusahaan (Herawaty, 2008).

Kepemilikian institusional dan kepemilikan manajerial dalam penelitian ini dijadikan sebagai variabel independen yang langsung mempengaruhi nilai perusahaan karena konflik keagenan antara agen dan prinsipal yang terjadi dalam suatu perusahaan dapat diminimumkan dengan suatu mekanisme yaitu dengan adanya saham oleh institusi dan manajemen yang diharapkan dapat meningkatkan nilai perusahaan. Rumusan masalah dalam penelitian ini yaitu apakah kepemilikian institusional, kepemilikan manajerial, berpengaruh terhadap nilai perusahaan manufaktur yang terdaftar di BEI tahun 2014-2016. Adapun tujuan penelitian yakni untuk mengetahui pengaruh kepemilikan institusional, kepemilikan manajerial, terhadap nilai perusahaan manufaktur yang terdaftar di BEI tahun 2014-2016. 
Kegunaan penelitian diharapkan mampu memberikan pengetahuan baru di bidang akuntansi, terutama yang berkaitan dengan pengaruh kepemilikan manajerial dan kepemilikan institusional terhadap nilai perusahaan yang dapat memperkuat atau memperlemah hubungan keduanya.

Menurut Rika dan Islahuddin (2008), nilai perusahaan didefinisikan sebagai nilai pasar, karena nilai pasar perusahaan dapat memberikan kemakmuran pemegang saham secara maksimum apabila harga saham perusahaan meningkat. Semakin tinggi harga saham, maka semakin tinggi kemakmuran pemegang saham. Dapat dicapai nilai perusahaan dengan yang maksimum bila pihak pemegang saham menyerahkan urusan pengelolaan suatu perusahaan dengan orang yang ahli dibidangnya misalnya komisaris dan juga.

Investor menggunakan rasio keuangan untuk mengetahui nilai pasar dalam suatu perusahaan. Dengan rasio keuangan ini dapat memberikan suatu indikasi untuk pihak manajemen tentang penilaian investor pada kinerja dari perusahaan di masa sebelumnya dan juga memberikan prospek di masa depan. Tobin's Q merupakan salah satu dari beberapa rasio keuangan yang dapat digunakan guna mengukur nilai pasar suatu perusahaan. Tobin's Q dapat dikatakan sebagai rasio terbaik dan dinilai bisa memberikan informasi paling baik karena menghitung dan memasukkan semua unsur penting dalam perusahaan seperti hutang dan juga modal saham perusahaan dan bukan hanya saham biasa dan juga bukan hanya ekuitas dari perusahaan dimasukkan tetapi seluruh aset dari perusahaan tersebut.

Kepemilikan institusional merupakan kepemilikan saham perusahaan yang dimiliki oleh institusi atau lembaga seperti perusahaan asuransi, bank, perusahaan investasi dan kepemilikaan lain (Tarjo, 2008). Kepemilikan institusional mempunyai makna penting 
untuk memonitor manajemen sebab dengan adanya kepemilikan oleh institusional dapat mendorong peningkatan pengawasan yang lebih optimal. Monitoring tersebut merupakan tentu dapat menjamin kemakmuran untuk pemegang saham kepemilikan institusional yang dimana sebagai agen pengawas untuk ditekan melalui investasi yang lumayan besar di pasar modal.

Bukti empiris mengenai pengaruh kepemilikan institusional terhadap nilai perusahaan ditunjukkan dalam penelitian yang dilakukan oleh Mokhtari dan Khosro (2013) menemukan bahwa kepemilikan institusional memiliki pengaruh yang positif dan signifikan terhadap nilai perusahaan. Hal ini sejalan dengan penelitian yang dilakukan oleh Thanatawee (2014) yang membuktikan bahwa kepemilikan institusional berpengaruh positif secara signifikan terhadap nilai perusahaan. Semakin besar kepemilikan institusional maka semakin efisien pemanfaatan aktiva perusahaan dan diharapkan juga dapat bertindak sebagai pencegahan terhadap pemborosan dan manipulasi laba yang dilakukan oleh manajemen sehingga akan meningkatkan nilai perusahaan. Hipotesis pertama dalam penelitian ini adalah:

\section{H1 : Kepemilikan institusional berpengaruh positif terhadap nilai perusahaan.}

Menurut Jensen dan Meckling mekanisme untuk mengatasi konflik keagenan antara lain dengan meningkatkan kepemilikan insider (insider ownership), sehingga dapat mensejajarkan kepentingan pemilik dengan manajer. Semakin bertambahnya saham yang dimiliki manajer, melalui kepemilikan manajerial akan memotivasi kinerja manajemen karena mereka merasa memiliki andil dalam perusahaan baik sebagai pengambil keputusan maupun dalam tanggung jawab atas setiap keputusan yng diambil. Sehingga pada akhirnya kinerja manajemen akan semakin baik dan berpengaruh pada peningkatan nilai perusahaan Adri, dkk (2014). 
Penelitian Rachman (2012) menyatakan bahwa meningkatnya kepemilikan manajerial akan berdampak positif pada nilai perusahaan karena dengan bertambahnya kepemilikan saham oleh pihak manajemen perusahaan maka kontrol pada aktivitas manajemen akan meningkat. Hasil ini sejalan dengan penelitian Ningsih (2013) yang menemukan bahwa variabel kepemilikan manajerial juga berpengaruh positif pada nilai perusahaan.

Hipotesis kedua dalam penelitian ini adalah:

\section{$\mathrm{H}_{2}$ : Kepemilikan manajerial berpengaruh positif terhadap nilai perusahaan.}

\section{METODE PENELITIAN}

Penelitian ini menggunakan pendekatan berbentuk asosiatif hubungan kausal. Lokasi penelitian yaitu perusahaan manufaktur yang terdaftar di Bursa Efek Indonesia periode 2014-2016 melalui web resmi www.idx.co.id. Objek penelitian yakni kepemilikan institusional, kepemilikan manajerial, serta nilai perusahaan. Jenis data yakni data kuantitatif. Sumber data yakni data sekunder. Penelitian menggunakan kepemilikan institusional, kepemilikan manajerial, sebagai variabel independen, dan nilai perusahaan sebagai variabel dependen.

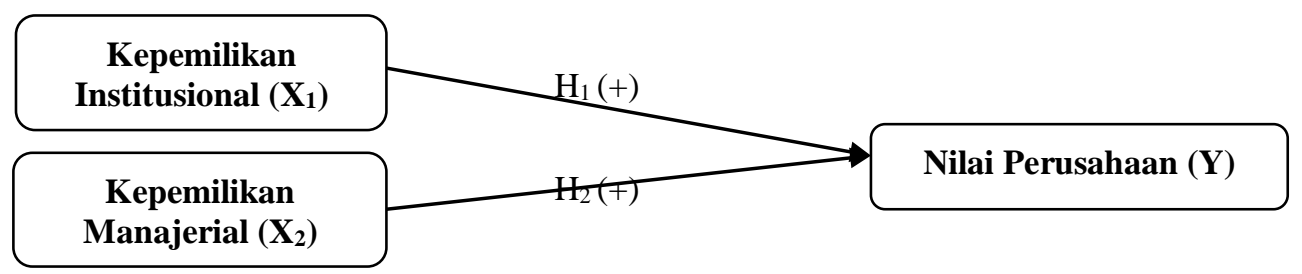

\section{Gambar 1. Desain Penelitian}

Sumber: Data Diolah ( 2017)

Penelitian ini menggunakan tiga tahun penelitian, yaitu tahun 2014, 2015, dan 2016. Populasi penelitian yakni seluruh perusahaan manufaktur pada Bursa Efek Indonesia tahun 
2014 hingga 2016, yaitu sejumlah 136 perusahaan. Proses penentuan sampel yakni dengan metode purposive sampling dengan tujuan mendapatkan sampel yang representative sesuai dengan kriteria yang ditentukan sehingga diperoleh 50 perusahaan sampel menggunakan tiga tahun pengamatan.

Adapun kriteria dalam pemilihan sampel, yakni kriteria pertama yaitu perusahaan manufaktur yang terdaftar di BEI secara berturut-turut selama tahun 2014-2016. Kriteria kedua yaitu menerbitkan laporan tahunan lengkap secara berturut-turut selama tahun 20142016. Dan kriteria ketiga yaitu memiliki data yang lengkap terkait dengan variabel yang digunakan dalam penelitian yaitu memiliki kepemilikan institusional, kepemilikan manajerial dalam laporan keuangannya.

\section{Tabel 1. Sampel Penelitian}

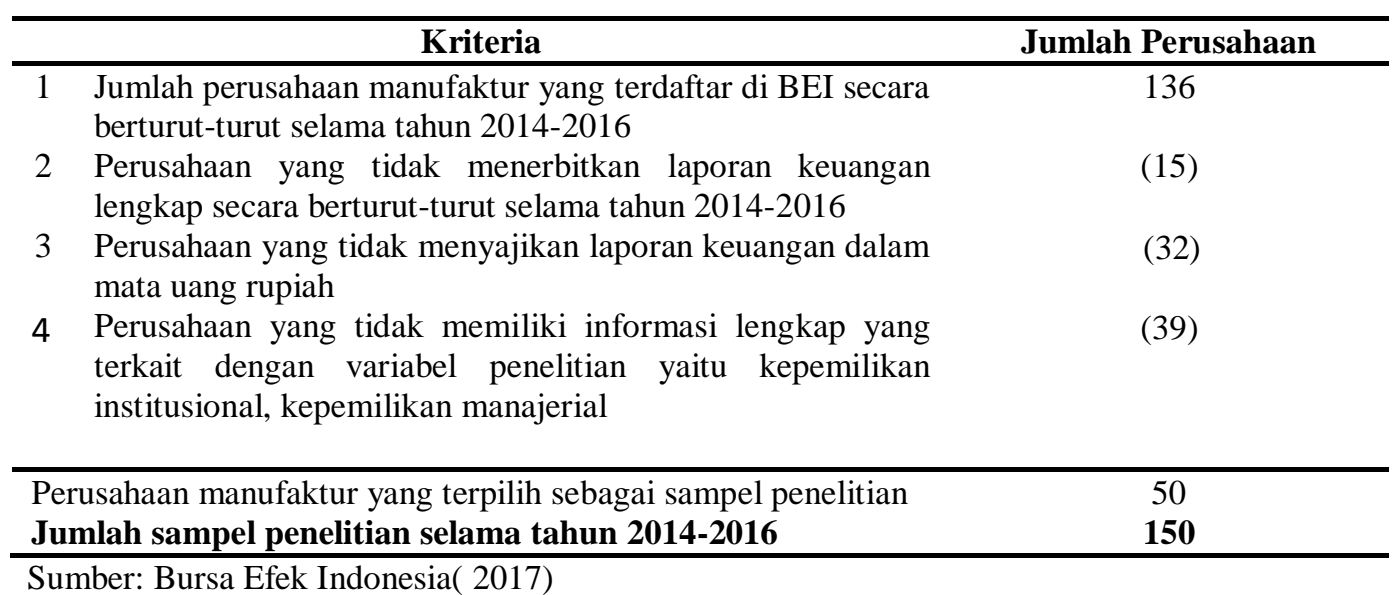

Metode di dalam mengumpulkan data penelitian ini adalah dengan suatu checklist pengungkapan sosial perusahaan. Dan dengan melalui studi dokumentasi dengan merampungkan data-data sekunder dari perusahaan tersebut melalui situs BEI yaitu www.idx.co.id.

Regresi linier berganda merupakan alat statistik yang digunakan agar kita dapat mengetahui pengaruh satu atau beberapa variabel yang diteliti. Alat bantu statistik berupa 
SPSS 23 digunakan untuk menganalisis perhitungan data. Model persamaan yang digunakan dalam penelitian yaitu:

$$
\mathrm{Y}=\alpha+\mathrm{b}_{1} \mathrm{X}_{1}+\mathrm{b}_{2} \mathrm{X}_{2}+\mathrm{e}
$$

Keterangan:

$\mathrm{Y}=$ Nilai Perusahaan

$\alpha \quad=$ Konstanta

$\mathrm{b}_{1}-\mathrm{b}_{2}=$ Koefisien Regresi

$\mathrm{X}_{1}=$ Kepemilikan Institusional

$\mathrm{X}_{2} \quad=$ Kepemilikan Manajerial

$\mathrm{e} \quad=$ Error Term

Nilai perusahaan diproksikan dengan rasio Tobin's Q. Rasio Tobin's Q dapat dihitung melalui rumus berikut:

$$
\mathrm{Q}=\frac{(\mathrm{EMV}+\mathrm{D})}{(\mathrm{EBV}+\mathrm{D})}
$$

Keterangan:

$\mathrm{Q}=$ Nilai perusahaan

$\mathrm{EMV}=$ Nilai pasar ekuitas

$\mathrm{EBV}=$ Nilai buku dari total ekuitas

$\mathrm{D} \quad=$ Nilai buku dari total hutang

Kepemilikan institusional dapat diukur melalui rumus berikut:

$$
\mathrm{KI}=\frac{\text { Kepemilikan Saham Institusional }}{\text { Total Saham Beredar }} \times 100 \%
$$

Keterangan:

$\mathrm{KI}=$ Kepemilikan Institusional

Kepemilikan manajerial dapat diukur melalui rumus berikut:

$$
\mathrm{KM}=\frac{\text { Kepemilikan Saham Manajerial }}{\text { Total Saham Beredar }} \times 100 \%
$$

Keterangan:

$\mathrm{KM}=$ Kepemilikan Manajerial 


\section{HASIL DAN PEMBAHASAN}

Berikut adalah hasil dan pembahasan dari uji yang digunakan dalam penelitian ini yaitu uji statistik deskriptif dimana memberikan suatu gambaran umum mengenai obyek dalam penelitian yang dijadikan sampel meliputi mean, maksimum, minimum, dan standar deviasi, lalu hasil dari dilakukannya uji asumsi klasik serta hasil dari dilakukannya pengujian terhadap hipotesis didalam penelitian ini.

\section{Tabel 2. Statistik Deskriptif}

\begin{tabular}{lccccc}
\hline & $\mathrm{N}$ & Minimum & Maximum & Mean & Std. Deviation \\
\hline KI & 84 & 0,3222 & 0,9799 & 0,679879 & 0,1747696 \\
KM & 84 & 0,0000 & 0,2777 & 0,048620 & 0,0802744 \\
CSR & 84 & 0,0879 & 0,5275 & 0,247507 & 0,1013874 \\
TOBINS'Q & 84 & 0,5095 & 1,4180 & 0,879611 & 0,2049584 \\
Valid N (listwise) & 84 & & & & \\
\hline ber: Data diolah (2016) & & & & &
\end{tabular}

Berdasarkan yang terdapat di dalam Tabel 2 maka dapat diketahui variabel kepemilikan institusional memiliki mean sebesar 0,679879 dimana ini berarti bahwa saham dari perusahaan yang dimiliki oleh institusi atau lembaga pada perusahaan manufaktur selama periode tahun 2013 sampai 2015 adalah sebesar 67,9879 persen. Standar deviasi sebesar 0,1747696 artinya selama tiga tahun, kepemilikan insitusional pada perusahan manufaktur terjadi penyimpangan dari rata-rata yaitu sebesar 17,47696 persen.

Rata-rata hitung (mean) kepemilikan manajerial sebesar 0,048620 dimana ini berarti persentase dari kepemilikan saham yang dimiliki oleh direksi, manajemen, komisaris perusahaan pada perusahaan manufaktur selama periode tahun 2013 sampai 2015 adalah sebesar 4,862 persen. Standar deviasi kepemilikan oleh pihak manajerial sebesar 0,0802744 artinya selama kurun waktu tiga tahun pengamatan atas kepemilikan oleh manajerial pada perusahan manufaktur terjadi penyimpangan dari rata-rata yakni sebanyak 8,02744 persen.

Nilai mean dari pengungkapan corporate social responsibility sebesar 0,247507 94 I w idya_akuntansi 
artinya dimana tanggung jawab sosial yang diungkapkan pada perusahaan manufaktur selama periode dari 2013 sampai 2015 adalah sebesar 0,247507. Standar deviasi sebesar 0,1013874 artinya selama tiga tahun, pengungkapan corporate social responsibility pada perusahaan manufaktur terjadi penyimpangan dari rata-rata yaitu 0,1013874 .

Nilai perusahaan yang dimana diproksikan Tobin's Q memiliki mean yaitu 0,879611. Standar deviasi sebesar 0,2049584 artinya selama tiga tahun, nilai perusahaan yang terdapat di perusahan manufaktur terjadi penyimpangn dari mean sebanyak 0,2049584 .

Tabel 3. Hasil Uji Normalitas

\begin{tabular}{|c|c|}
\hline \multicolumn{2}{|c|}{ Uji Kolmogorov-Smirnov } \\
\hline $\mathrm{N}$ & 84 \\
\hline Kolmogorov - Smirnov Z & 0,080 \\
\hline Asym. Sig ( 2 - tailed ) & 0,200 \\
\hline
\end{tabular}

Sumber: Data diolah (2016)

Dari Tabel 3 dapat diketahui hasil uji Kolmogorov - Smirnov yaitu sebesar 0,080 dengan nilai signifikan yang diperoleh sebesar 0,200. Maka dari hasil ini dapat memperlihatkan bahwa keempat variabel memiliki data terdistribusi secara normal.

Tabel 4. Hasil Uji Multikolinearitas

\begin{tabular}{ccc}
\hline \multirow{2}{*}{ Model } & \multicolumn{2}{c}{ Collinearity Statistics } \\
\cline { 2 - 3 } & Tolerance & VIF \\
\hline KI & 0,782 & 1,278 \\
KM & 0,797 & 1,254 \\
CSR & 0,931 & 1,075 \\
\hline
\end{tabular}

Sumber: Data diolah (2016)

Dilihat dari Tabel 4 dapat ditunjukkan bahwa nilai VIF dari ketiga variabel bebas memiliki hasil dibawah angka 10 serta dapat dilihat nilai tolerance dari ketiga variabel bebas diatas angka 0,10. Maka dengan ini dapat disimpulkan tidak adanya multikolinearitas yang terjadi diantara variabel - variabel bebasnya. 
Tabel 5. Hasil Uji Autokolerasi

\begin{tabular}{cccccc}
\hline Model & $\mathrm{R}$ & R square & $\begin{array}{c}\text { Adjusted R } \\
\text { Square }\end{array}$ & $\begin{array}{c}\text { Std. Error of } \\
\text { The Estimate }\end{array}$ & $\begin{array}{c}\text { Durbin } \\
\text { Watson }\end{array}$ \\
\hline 1 & $0,569^{\mathrm{a}}$ & 0,324 & 0,299 & 0,1716147 & 1,745 \\
\hline Sumber:
\end{tabular}

Sumber: Data diolah (2016)

Berdasarkan Tabel 5 menunjukkan nilai DW sebesar 1,745. Berdasarkan tabel DW dengan jumlah sample $n=84$ serta variabel bebasnya $k=3$ maka didapat hasil dari nilai $d_{L}$ yaitu 1,57 dan $d_{U}$ yaitu 1,72 . Nilai dari yang diperoleh DW 1,745 terletak antara $d_{U}(1,72)$ dan 4-d $\mathrm{d}_{\mathrm{U}}(2,28)$ maka dengan hasil demikian dapat ditunjukkan model dari regresi terbebas oleh autokolerasi.

\section{Tabel 6. Uji Heteroskedastisitas}

\begin{tabular}{|c|c|c|c|c|c|c|}
\hline \multirow[b]{2}{*}{ Model } & & \multicolumn{2}{|c|}{$\begin{array}{c}\text { Unstandardized } \\
\text { Coefficients }\end{array}$} & \multirow{2}{*}{$\begin{array}{l}\text { Standardized } \\
\text { Coefficients } \\
\text { Beta }\end{array}$} & \multirow[b]{2}{*}{$\mathrm{t}$} & \multirow[b]{2}{*}{ Sig. } \\
\hline & & $\mathrm{B}$ & Std. Error & & & \\
\hline & (Constant) & 0,096 & 0,071 & & 1,342 & 0,183 \\
\hline & $\mathrm{KI}$ & $-0,005$ & 0,077 & $-0,007$ & $-0,059$ & 0,953 \\
\hline & KM & 0,217 & 0,166 & 0,161 & 1,309 & 0,194 \\
\hline & CSR & 0,102 & 0,122 & 0,096 & 0,841 & 0,403 \\
\hline
\end{tabular}

Sumber: Data diolah (2016)

Dari Tabel 6 dapat dilihat nilai signifikansi dari variabel bebas sudah lebih dari 5\% yang dapat diartikan bahwa tidak terdapat hubungan antara variabel bebasnya dengan nilai residu sehingga tidak terjadi nya heteroskedastisitas didalam penelitian ini.

Tabel 7. Analisis Regresi Linear Berganda

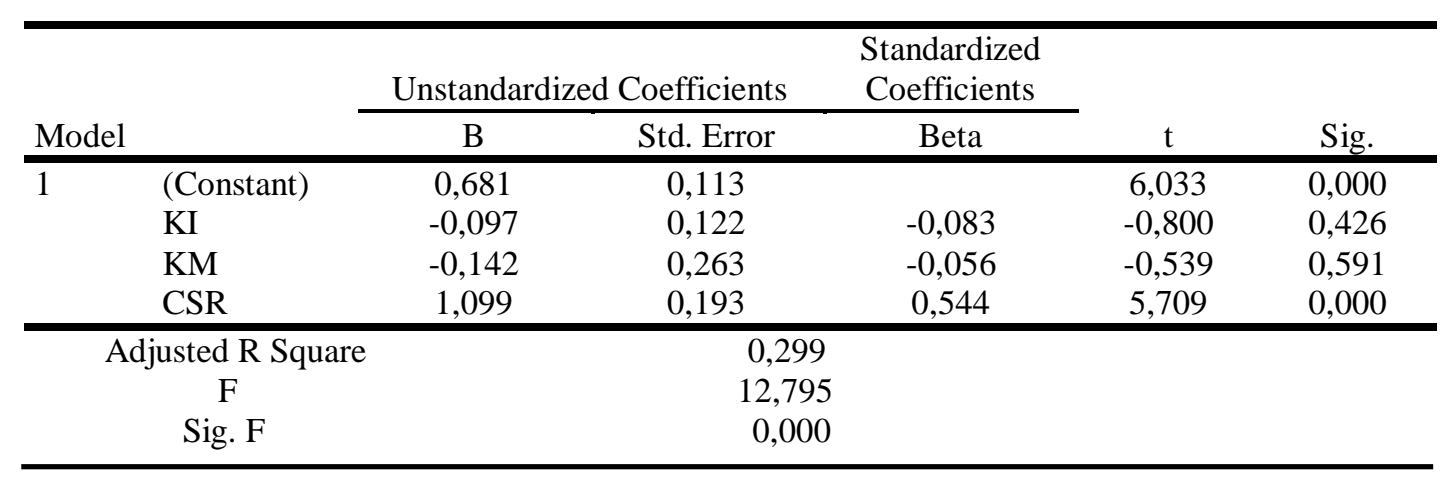

Sumber: Data diolah (2016) 
Dengan melihat Tabel 7 dapat disusun persamaan dari regresi linear berganda yaitu seperti berikut:

$$
\mathrm{Y}=0,681-0,097 \mathrm{X}_{1}-0,142 \mathrm{X}_{2}+1,099 \mathrm{X}_{3}+\mathrm{e}
$$

Persamaan diatas dapat menjelaskan bahwa jika kepemilikan institusional, kepemilikan manajerial dan pengungkapan corporate social responsibility sebesar 0 maka nilai perusahaan sebesar 0,681 . Jika kepemilikan institusional mengalami kenaikan satu satuan maka nilai perusahaan mengalami penurunan sebesar 0,097. Apabila kepemilikan manajerial mengalami kenaikan sebesar satu satuan maka nilai perusahaan menurun sebesar 0,142. Dan apabila pengungkapan corporate social responsibility mengalami kenaikan satu satuan maka nilai perusahaan akan mengalami peningkatan sebesar 1,099.

Nilai adjusted R-Square yang dihasilkan adalah sebesar 0,299 menunjukkan bahwa variabel kepemilikan institusional $\left(\mathrm{X}_{1}\right)$, kepemilikan manajerial $\left(\mathrm{X}_{2}\right)$ dan pengungkapan corporate social responsibility $\left(\mathrm{X}_{3}\right)$ mampu mempengaruhi nilai perusahaan $(\mathrm{Y})$ sebesar 29,9\%. Sedangkan sisanya sebesar 70,1\% dipengaruhi oleh variabel lain yang tidak diteliti.

Uji F digunakan untuk mengetahui apakah model regresi layak digunakan untuk menjelaskan pengaruh variabel-variabel bebas terhadap variabel terikat. Berdasarkan Tabel 7 nilai $\mathrm{F}$ hitung adalah 12,795 dengan tingkat signifikansi sebesar 0,000 lebih kecil dari taraf nyata sebesar 0,05 ini berarti bahwa model yang digunakan dalam penelitian ini adalah layak. Hal ini bermakna bahwa kepemilikan institusional, kepemilikan manajerial dan pengungkapan corporate social responsibility secara serempak berpengaruh terhadap nilai perusahaan.

Uji t digunakan untuk mengetahui apakah variabel bebas berpengaruh secara parsial terhadap variabel terikat. Untuk menentukan apakah hipotesis diterima atau ditolak adalah 
dengan melihat nilai signifikansi dalam penelitian ini menggunakan tingkat signifikansi 0,05 .

Pengujian hipotesis Pertama $\left(\mathrm{H}_{1}\right)$ pada menunjukkan nilai t hitung KI sebesar $-0,800$ dengan tingkat signifikansi sebesar 0,426 yang jauh lebih besar dari taraf nyata 0,05. Hipotesis pertama menyatakan bahwa kepemilikan institusional berpengaruh positif terhadap nilai perusahaan. Berdasarkan hasil analisis menunjukkan nilai uji t hitung sebesar -0,800 dengan tingkat signifikansi 0,426 yang jauh lebih besar dari taraf nyata sebesar 0,05. Sehingga disimpulkan bahwa kepemilikan institusional tidak mempengaruhi nilai perusahaan. Hasil ini berarti bahwa semakin besar persentase kepemilikan saham dari luar perusahaan tidak mampu meningkatkan nilai perusahaan manufaktur yang terdaftar di Bursa Efek Indonesia (BEI). Berdasarkan hal tersebut maka hipotesis pertama ditolak.

Pada Tabel 7 kepemilikan institusional menunjukkan berpengaruh negatif dengan nilai koefisien -0,097. Hasil ini dapat menyatakan bahwa dengan semakin tingginya kepemilikan institusional didalam perusahaan maka dapat menyebabkan penurunan nilai dari suatu perusahaan tetapi nilai probabilitas signifikansinya yaitu sebesar 0,426 maka dapat ditarik kesimpulan bahwa kepemilikan institusional tidak mempengaruhi nilai perusahaan.

Kepemilikan institusional yang tinggi dengan mencapai rata-rata yaitu 67,9\% merupakan pemilik mayoritas perusahaan. Menurut Pound, investor institusional mayoritas mempunyai kecenderungan berpihak atau berunding dengan pihak manajemen saja dan dapat mengabaikan kepentingan dari pemegang saham minoritas.

Investor institusional merupakan pemilik sementara (transfer owner) sehingga investor institusional cenderung hanya terfokus pada laba yang sekarang (current earnings). Berubahnya laba yang sekarang bisa mempengaruhi keputusan dari investor 
institusional perusahaan. Bila perubahan tersebut dirasakan tidak atau belum menguntungkan oleh para investor maka para investor dapat melalukan penarikan sahamnya yang dimana investor institusional biasanya memiliki saham dengan proporsi yang besar, maka bila mereka menarik sahamnya dengan tiba-tiba maka akan dapat mempengaruhi nilai saham secara keseluruhan. Hal ini dapat diartikan bahwa kepemilikan institusional belum mampu menjadi suatu indikator yang dapat meningkatkan nilai dari suatu perusahaan.

Penelitian ini mendukung hasil penelitian dari Demsetz and Villalonga (2001) dan Chilin Lu et al., (2007). Dan juga Hexana Sri Lastanti (2004) serta Wahyudi dan Pawesti (2006) yang dimana menemukan bahwa meskipun kepemilikan institusional tinggi namun tidak berpengaruh terhadap nilai perusahaan.

Pengujian hipotesis kedua $\left(\mathrm{H}_{2}\right)$ menunjukkan nilai t hitung $\mathrm{KM}$ sebesar -0,539 dengan tingkat signifikansi sebesar 0,591 yang jauh lebih besar dari taraf nyata 0,05. Hipotesis kedua menyatakan bahwa kepemilikan manajerial berpengaruh positif terhadap nilai perusahaan. Berdasarkan hasil analisis uji t hitung menunjukkan sebesar -0,539 dengan tingkat signifikansi sebesar 0,591 yang jauh lebih besar dari taraf nyata 0,05. Sehingga dapat disimpulkan bahwa kepemilikan manajerial tidak mempengaruhi nilai perusahaan. Hasil ini berarti bahwa semakin banyak saham yang dimiliki oleh manajemen seperti direksi, manajemen, komisaris maupun pihak yang terlibat secara langsung dalam pembuatan keputusan perusahaan belum mampu meningkatkan nilai perusahaan manufaktur yang terdaftar di Bursa Efek Indonesia (BEI). Berdasarkan hal tersebut maka hipotesis kedua ditolak.

Pada Tabel 7 kepemilikan manajerial menunjukkan pengaruh negatif dengan koefisien $-0,142$. Hasil ini dapat menunjukkan jika semakin tinggi kepemilikan manajerial 
dalam suatu perusahaan maka dapat menurunkan nilai perusahaan namun nilai probabilitas signifikansinya sebesar 0,591 maka dapat ditarik kesimpulan bahwa kepemilikan manajerial tidak berpengaruh terhadap nilai perusahaan.

Hal ini dapat disebabkan karena kepemilikan manajerial pada perusahaan manufaktur di Indonesia memiliki kecenderung masih sangat rendah dan hasil itu ditunjukan dari hasil uji analisi statistik deskriptif yang dimana rata-rata dari presentase kepemilikan manajerial hanya sebanyak 4,8\%. Minimnya kepemilikan dari saham yang dimiliki oleh pihak manajemen menyebabkan pihak dari manajemen belum dapat ikut merasakan sebagai pemilik dari perusahaan tersebut sebab tidak semua dari keuntungan bisa dirasakan oleh pihak manajemen sehingga mengakibatkan pihak manajemen ingin untuk memaksimalkan utilitas sendiri saja dan dimana dapat merugikan pihak pemegang saham lainnya.

Penelitian tersebut sejalan dengan penelitian Mohd Hassan Che Haat (2008). Serta Sujoko dan Soebiantoro (2007) juga menghasilkan simpulan bahwa kepemilikan manajemen tidak berpengaruh terhadap nilai perusahaan.

Hasil penelitian ini berupaya menjelaskan bahwa peningkatan jumlah kepemilikan manajerial tidak mampu mengurangi konflik agensi yang timbul akibat hubungan keagenan. Jumlah kepemilikan manajerial yang besar tidak mampu mensejajarkan kepentingan manajemen dan pemegang saham, sehingga tujuan perusahaan dalam mencapai nilai perusahaan yang tinggi tidak dapat tercapai. Para manajer memiliki kepentingan yang cenderung dipenuhinya dibandingkan dengan pencapaian tujuan perusahaan secara keseluruhan. Hasil penelitian ini sesuai dengan hasil penelitian Chilin (2007) dan Juhandi (2013).

Pengujian hipotesis ketiga $\left(\mathrm{H}_{3}\right)$ menunjukkan nilai t hitung CSR sebesar 5,709 dengan tingkat signifikansi sebesar 0,000 yang lebih kecil dari taraf nyata 0,05. Hipotesis 
ketiga menyatakan bahwa pengungkapan corporate social responsibility berpengaruh positif terhadap nilai perusahaan. Berdasarkan hasil analisis uji t hitung menunjukkan sebesar 5,079 dengan tingkat signifikansi sebesar 0,000 yang lebih kecil dari taraf nyata 0,05. Sehingga dapat disimpulkan bahwa pengungkapan corporate social responsibility berpengaruh posittif terhadap nilai perusahaan. Hasil ini berarti bahwa semakin tinggi pengungkapan corporate social responsibility maka mampu meningkatkan nilai perusahaan pada perusahaan Manufaktur yang terdaftar di Bursa Efek Indonesia (BEI). Berdasarkan hal tersebut maka hipotesis ketiga diterima.

Pada Tabel 7 pengungkapan corporate social responsibility menunjukkan nilai koefisien sebesar 1,099 dan probabilitas signifikansi 0,000 sehingga dapat disimpulkan bahwa pengungkapan corporate social responsibility berpengaruh positif terhadap nilai perusahaan. Hasil ini dapat disimpulkan bahwa semakin tinggi tingkat pengungkapan tanggung jawab sosial perusahaan maka dapat meningkatkan nilai perusahaan. Hal ini diakibatkan karena dengan adanya pengungkapan tanggung jawab sosial perusahaan maka akan direspon positif oleh investor sehingga banyak investor yang berinvestasi pada perusahaan tersebut yang menyebabkan meningkatnya nilai perusahaan.

Terjadinya lonjakan perdagangan juga mengakibatkan meningkatnya jumlah laba, karena meningkatnya penjualan dan pengungkapan tanggung jawab social yang banyak, dan akan mengakibatkan investor tertarik untuk menginvestasikan sahamnya ke perusahaan. Hal ini dapat disimpulkan bahwa semakin tinggi tingkat pengungkapan tanggung jawab sosial perusahaan dapat meningkatkan nilai perusahaan. Penelitian ini mendukung penelitian dari Rika dan Islahuddin (2008) serta Etty Murwaningsari (2009) dan Wien Ika (2010). 


\section{SIMPULAN DAN SARAN}

Berdasarkan pada hasil analisis dan pembahasan pada penelitian ini dapat ditarik kesimpulan yaitu kepemilikan institusional atau kepemilikan saham oleh pihak luar perusahaan dan kepemilikan manajerial atau kepemilikan saham oleh pihak manajemen tidak mempengaruhi nilai perusahaan pada perusahaan manufaktur yang terdaftar di Bursa Efek Indonesia (BEI) tahun 2013-2015, sedangkan pengungkapan corporate social responsibility berpengaruh positif terhadap nilai perusahaan pada perusahaan manufaktur yang terdaftar di Bursa Efek Indonesia (BEI) tahun 2013-2015.

Saran yang dapat diberikan berdasarkan pada simpulan penelitian adalah Saran bagi investor institusional yang merupakan pemilik saham mayoritas hendaknya tidak terlalu mementingkan kepentingan pribadi dan tidak mengabaikan pemegang saham minoritas agar tidak terjadi kesenjangan kesejahteraan yang semakin melebar.

\section{DAFTAR PUSTAKA}

Abbas, Asad. 2013. Impact of Large Ownership on Firm Performance: A Case of non Financial Listed Companies of Pakistan. World Applied Sciences Journal, 21 (8), pp: 1141-1152.

Ayu Rizqia, Dwita, Siti Aisjah, dan Sumiati. 2013. Effect of Managerial Ownership, Financial Leverage, Profitability, Firm Size, and Investment Opportunity on Dividend Policy and Firm Value. Research Journal of Finance and Accounting, vol.4, no.11, ISSN: 2222-2847

Badan Pengawas Pasar Modal dan Lembaga Keuangan. 2006. Kewajiban Penyampaian Laporan Tahunan Bagi Emiten atau Perusahaan Publik. Jakarta.

Barnea, Amir and Amir, Rubin. 2005. Corporate Social Responsibility as a Conflict Between Shareholders.

Bursa Saham Indonesia. www.idx.co.id. Diakses tanggal 10 Oktober 2016

Chariri, Anis dan Imam, Ghozali. 2007. Teori Akuntansi. Badan Penerbit UNDIP. Semarang.

Chilin dan Grace M. Liao. 2007. Ownership Structure, Information Disclosure and Corporate Value: An Empirical Analysis of Taiwan Companies. Proceedings of the 13 Asia Pacific Management Conference, Melbourne, Australia, pp: 698-704. 
Diyah, Pujiati dan Widanar, Erman. 2009. Pengaruh Struktur Kepemilikan terhadap Nilai Perusahaan: Keputusan Keuangan sebagai Variabel Intervening. Jurnal Ekonomi Bisnis dan Akuntansi Ventura. Vol. 12. No.1. h. 71-86.

Demsetz, Harold and Belen Villalonga. 2001. Ownership Structure and Corporate Performance. Journal of Corporate Finance, pp. 209-233.

Faizal. 2004. Analisis Agency Costs, Struktur Kepemilikan dan Mekanisme Corporate Governance. Simposium Nasional Akuntansi VII. Denpasar.

Ghozali, Imam. 2009. Aplikasi Analisis Multivariate dengan Program SPSS Edisi 4. Badan Penerbit Universitas Diponegoro. Semarang.

Hackston, D., and Milne, M. 1996. Some determinants of social and environmental disclosures in New Zealand companies. Accounting. Auditing \& Accountability Journal. Vol. 9. Pp.22-108.

Haruman, Tendi. 2008. Pengaruh Struktur Kepemilikan terhadap Keputusan Keuangan dan Nilai Perusahaan. Simposium Nasional Akuntansi XI, Pontianak.

Hassan, M. Che Haat, Rahman, Rashidah Abdul, dan Mahenthiran, Sakthi. 2008. Corporate governance, transparency and performance of Malaysian companies. Managerial Auditing Journal, Vol. 23, No. 8, pp. 744-778

Hendriksen, Eldon S. dan M. Brenda. 2000. Teori Akunting Edisi 5. Interaksara. Batam.

Ikatan Akuntan Indonesia. 2015. Standar Akuntansi Keuangan. Salemba Empat. Jakarta

Jensen, M.C., dan Meckling, W.H. 1976. Theory of the Firm: Managerial Behavior, Agency Costs, and Ownership Structure. Journal of Financial Economics, vol.3, pp: 305-360

Jo Hoje, Harjoto Maretno A. 2011. Corporate Governance and Firm Value: The Impact of Corporate Social Responsibility. Journal of Business Ethics. 2011.

Juhandi, Nendi. 2013. The Effects of Internal Factors and Stock Ownership Structure on Dividend Policy on Company's Value [A Study on Manufacturing Companies Listed on the Indonesia Stock Exchange (IDX)]. International Journal of Business and Management Invention, 2 (11), pp: 6-18.

Kumar, Jayesh. 2011. Does Ownership Structure Inuence Firm Value? Evidence from India. Indira Gandhi Institute of Development Research, pp: 1-44.

Mardikanto, Totok. 2014. Corporate Social Responsibility. Alfabeta. Bandung.

Navissi, Farshid and Naiker, Vic. 2006. Institutional Ownership and Corporate Value. Journal of Managerial Finance, Vol. 32, No.1, pp.247-256.

Nurhayati, Ratna, Allistair, Brown, dan Greg, Tower. 2006. Natural Environment Disclosures of Indonesian Listed Company. Paper Submission at AFAANZ Conference, Welington, New Zealand. 
Nurlela, Rika dan Ishlahuddin. 2008. Pengaruh Corporate Social Responsibility terhadap Nilai Perusahaan dengan Prosentase Kepemilikan Manajemen sebagai Variabel Moderating. Simposium Nasional Akuntansi XI, Pontianak.

Prasetyaning, Hartini Pawestri. 2006. Implikasi Struktur Kepemilikan terhadap Nilai Perusahaan dengan Keputusan Keuangan sebagai Variabel Intervening. Simposium Nasional Akuntansi IX. Padang 23-26 Agustus.

Permanasari, Wien Ika. 2010. Pengaruh Kepemilikan Manajemen, Kepemilikan Institusional, dan Corporate Social Responsibility terhadap Nilai Perusahaan. Skripsi. Universitas Diponegoro

Sayekti, Yosefa dan Wondabio, Ludovicud Sensi. 2007. Pengaruh CSR Disclosure terhadap Earning Response Coefficient. Simposium Nasional Akuntansi X. Makassar

Saham OK. www.sahamok.com. Diakses tanggal 16 Oktober 2016

Siallagan, Hamonangan, dan Machfoedz, Mas'ud. 2006. Mekanisme Corporate Governance, Kualitas Laba dan Nilai Perusahaan. Simposium Nasionl Akuntansi IX. Padang

Siregar, Syofian. 2013. Metode Penelitian Kuantitatif. Kencana Predana Media Group. Jakarta.

Suranta, Edi dan Puspita, Pratama Merdistuti. 2003. Analisis Hubungan Struktur Kepemilikan Manajerial, Nilai Perusahaan dan Investasi dengan Model Persamaan Linear Simultan. Jurnal Riset Akuntansi Indonesia. Vol. 6. No.1.h.54-68

Suripto, Bambang. 1999. Pengaruh Karakteristik Perusahaan terhadap Pengungkapan Sukarela dalam Laporan Tahunan. Simposium Nasional Akuntansi. Malang

Tarjo. 2008. Pengaruh Konsentrasi Kepemilikan Institusional dan Leverage terhadap Manajemen Laba, Nilai Pemegang Saham serta Cost of Equity Capital. Simposium Nasional Akuntansi XI. Pontianak. 